\title{
NEDESTRUKTIVNÍ PRŮZKUM POLNÍCH SYSTÉMŮ A STRUKTURY ZÁSTAVBY ZANIKLÉ STŘEDOVĚKÉ VESNICE VOJŠICE (OKRES HODONÍN)
}

\author{
PETR DRESLER - PETER MILO - TOMÁŠ TENCER - MICHAL VÁGNER - MIROSLAV \\ DEJMAL
}

\begin{abstract}
Abstrakt: V rámci společného botanicko-archeologického projektu Masarykovy university, který se zabýval dopadem pravékého osídlení na vznik a udržení luk v Karpatech, se podařilo analýzou dat digitálního výškopisu České republiky identifikovat v NPR Čertoryje systémy vyvýšených liniových útvarů, které byly interpretovány jako pozůstatky mezi - polních systémů neznámého stář́. Vjejich těsné blizkosti se nachází zaniklá středověká vesnice Vojšice, kde byl proveden geofyzikální průzkum. Ten v těchto místech odhalil koncentrace anomálií, které byly interpretovány jako pozůstatky několika usedlostí. Jejich umistěni koreluje jak s nově zjištěnými mezemi, tak i s parcelací zachycenou na historických mapách.
\end{abstract}

Klíčová slova: zaniklá středověká vesnice - dálkový průzkum Země - plužiny - geofyzikální prospekce historické mapy.

Non-destructive research into the field systems and the structure of the built-up area of the deserted medieval village of Vojšice (Hodonín district)

\begin{abstract}
The joint botanical-archaeological project of Masaryk University, Brno focused on the impact of prehistoric settlement on the origination and sustenance of meadows in the Carpathians, where systems of elevated line formations interpreted as the remains of balks, field systems of unknown age, were identified in the Certoryje Nature Reserve, through the analysis of data of the digital altimetry of the Czech Republic. The geophysical survey was conducted on the site of the deserted medieval village of Vojšice, once situated in close proximity of these systems. The survey revealed a concentration of anomalies which were interpreted as the remains of several homesteads. Their location correlates both with the newly disclosed balks and the plot division captured by historical maps.
\end{abstract}

Key words: deserted medieval village - remote sensing - deserted medieval fields - geophysical survey historical maps.

\section{Úvod}

Zaniklá ves Vojšice se nalézá na rozhraní katastrů obcí Kněždub a Hrubé Vrbky (okr. Hodonín), a to necelých $3,6 \mathrm{~km}$ západně od středu druhé ze jmenovaných obcí. Lokalita se nachází na zákonem chráněných loukách NPR Čertoryje náležící pod CHKO Bílé Karpaty, v mírně svažitém terénu s nadmořskou výškou zhruba $360 \mathrm{~m}$ n. $\mathrm{m}$. Západně od zaniklé vsi protéká ŕíčka Radějovka, která obtéká z východní strany nedaleký vrch Čertoryje.

V žádných nám známých písemných pramenech se o vesnici nedochovala jediná přímá zmínka. Místní lokalitu dobře znají, ale do širšího povědomí se dostala až v 70. letech 20. století, kdy byly patrně poprvé od středověku okolní travnaté louky rozorány jako náhrada za půdu zabranou stavbami v rámci socialistického plánu práce. Díky získané kolekci keramiky a jedné železné ostruze bylo možné datovat lokalitu nejen do období vrcholného středověku, ale i do pravěku. Přitom publikovaný a dnes dostupný materiál lze datovat, krom pravěku a protohistorie, do druhé poloviny 13. až 14. století (Měřínský 1974, 76-77, Tab. 80; Snášil 1972, 107-109; Tribula 1973, 82-83). Osu vesnice měl, dle získaných nálezů, tvořit potok Radějovka (dřive Vojšický potok), přičemž při jeho úpravě a přilehlé orbě měly být patrny jednotlivé usedlosti (Snášil 1972, 107-109).

Kromě vesnice samotné se pozornost archeologů obrátila i na tzv. Žižkův stůl, nepatrnou vyvýšeninu obtékanou Radějovkou, kde se mělo nacházet drobné stř̌edověké opevnění. Archeologickou sondáží se však tuto domněnku nepodařilo zcela potvrdit. Autoři výzkumu (J. Tribula a J. Unger) opevnění zprvu klasifikovali jako hrádek, později ho označili jako chráněnou 
lokalitu. Naopak R. Snášil interpretuje terénní relikt jako pozůstatek speciálního hospodářského anebo výrobního zařízení - pravděpodobně vodního mlýna (Nekuda 1961, 157; Unger 1967, 232-233; Nekuda-Unger 1981, 315-316; Snášil 1972, 107-109; Tribula-Unger 1970, 95-100).

Další prospekce v okolí zaniklé vesnice byla provedena na počátku 90. let 20. století J. Pavelčíkem z muzea v Uherském Brodě, který zde kromě keramiky 13. až 14. století objevil i keramiku kultury s kanelovanou keramikou a fragmenty keramiky z doby římské (Pavelčík 1991, 65). Od poloviny 90. let je pravobřežní prostor opět zatravněn a povrchová prospekce tak není možná. Prostor vesnice je v posledních patnácti letech naneštěstí také v hledáčku nelegální detektorové prospekce. $Z$ ní pochází ojedinělé kovové, zejména pak železné nálezy, které jsou povětšinou v soukromém držení, tudíž obtížně dostupné. Jediný známý soubor železných předmětů získaný detektorovou prospekcí pochází od místního amatérského „hledače pokladů“, od kterého se nálezy i s dokumentací dostaly do Masarykova muzea v Hodoníně. Soubor je aktuálně ve stadiu konzervace a dokumentace.

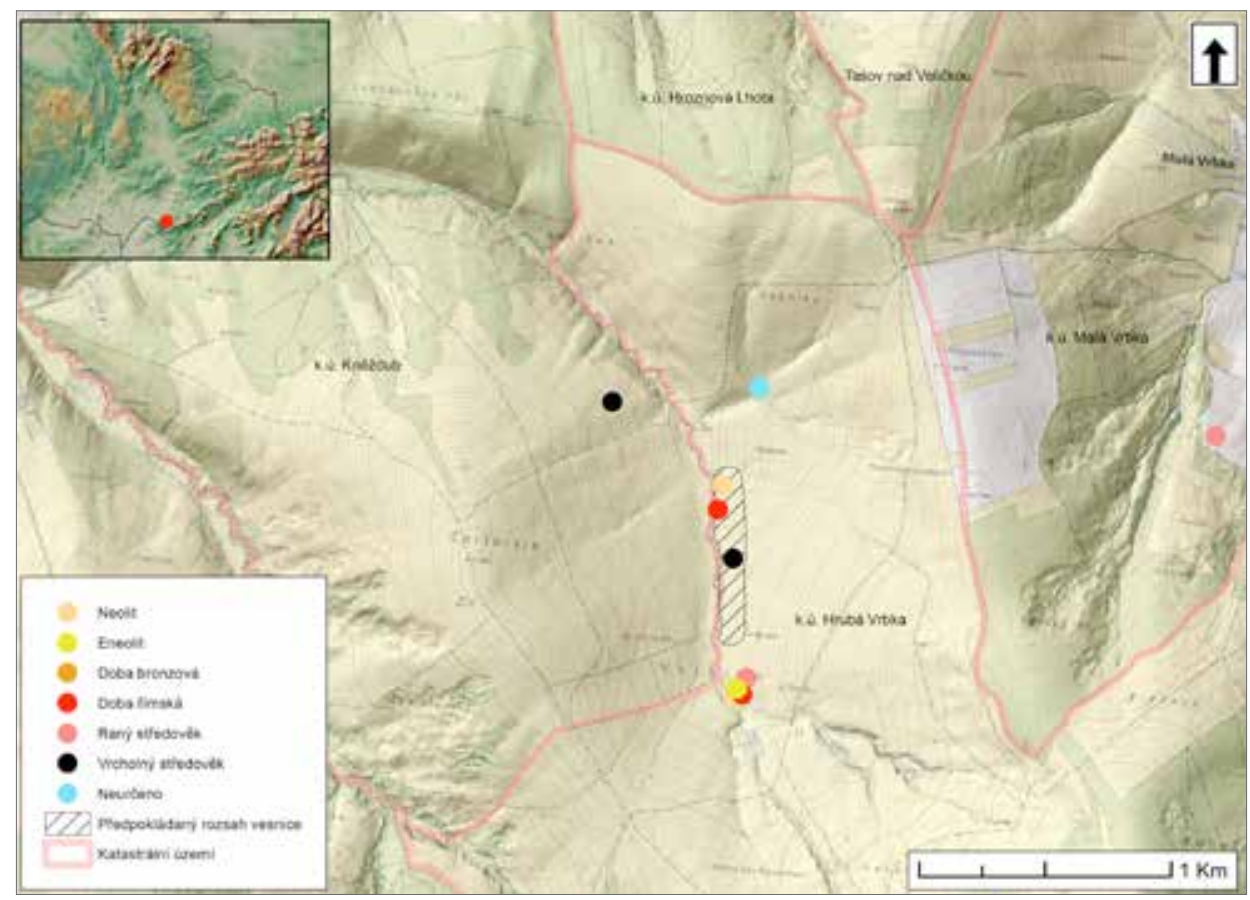

Obr. 1. Lokalizace ZSV Vojšice na výřezu mapy ZM 10 s vyznačenými nálezy z ostatních období v okolí lokality. Abb. 1. Lokalisierung der mittelalterlichen Dorfwüstung Vojšice auf einem Kartenausschnitt aus der Grundkarte ZM 10 mit eingezeichneten Funden aus den übrigen Zeiträumen in der Umgebung der Fundstelle.

\section{Historický exkurz}

Proces středověkého osídlovaní jihozápadních svahů Bílých Karpat byl ovlivňován specifickou situací na tehdejší moravsko-uherské hranici, která těmito místy procházela. V 11. a 12. století byla celá oblast mezi řekami Moravou, Váhem a říčkami Olšavou a Chvojnicí součástí tzv. Lucka či Konfínia. Šlo o záměrně pusté území sloužící jako nárazová zóna mezi tehdejším českým a uherským státem. Z uherské strany známe i přísné zákazy jakékoliv výstavby a osídlovaní tohoto prostoru a organizaci obrany svěřené kmenům Sikulů a Pečeněhů. Situace se postupně 
začala měnit na konci 12. století, kdy začal být původní pustý prostor narušován nově vzniklým osídlením jak z moravské, tak i z uherské strany. K urychlení tohoto procesu došlo patrně v první polovině 13. století. Ve spojení s postupující vnitřní kolonizací nastalo období relativního klidu při držbě Břeclavska (až po Kunovice), a současné držby Trnavska na uherské straně, královnou Konstancií uherskou (1202?/1230-1237). Tehdy se hranice pravděpodobně ustálila na toku Moravy a říčky Veličky. Námi sledovaný prostor, který se nachází jižně Veličky, ovšem nebyl plně pod kontrolou uherského státu a byl jím pouze nárokován. To potvrzuje listina z roku 1217, která vyděluje „pustou zem Skalica“ (souhrnně Mitáček 2008, 155-167) a vcelku přesně vypočítává hranice uherského Skalicka. Východní hranice vede od ústí potoka Chvojnice (Hoynicha), dále po toku Moravy (Morowa), až k ústí ŕíčky Veličky (Velika). Hranice pak dále pokračuje po Veličce nejspíše až k dnešnímu Tasovu (portum Thozoy). Další trasa je totožná s tzv. cestou českých stráží (viam exploratorum de Bohemia), též zvanou Symarut. Poté hranice směřuje k pramenům potoka Vojšice (caput paludis Wysich - dnes Radějovka), odkud se táhne dále směrem na východ. Následně vede lesem přes jakýsi hřeben, kde byla louka. Odtud sestupuje údolím na pole zvané Hwzewmezen. Z tohoto pole pak vede k počátku pramene Chvojnice a po ní až k Moravě (CDS1 I, 174-175 č. 221, k ztotožnění lokalit Jan 2002, 46-47). Znova je pramen potoka Vojšice (caput paludis Woysych) vzpomínán ještě v obdobné listině z roku $1256(\mathrm{CDB}$ V/3, 82-83 č. 1066).

Agilnější postup při osídlování bývalého Lucka z moravské strany vrcholil na začátku 60. let 13. století, kdy byla - nejspíše po bitvě u Kressenbrunnu v roce 1260 - připojena oblast Strážnicka a hranice se přesunula na Sudoměřský potok, kde se nachází v podstatě dodnes. Bohužel pro celou oblast Strážnicka trpíme problémy s dochovanými písemnými prameny ze 13.-14. století. Samotná Strážnice je poprvé připomínána až v roce 1302 (CDM V, 135 č. 130). Ještě horší je to $\mathrm{v}$ prŕípadě jednotlivých vesnic panství. Radějov se poprvé připomíná až v roce 1412 (Hosák 2004, 416), Tvarožná Lhota v roce 1475 (Pajer 2002, 357, C1), Kněždub 1475 (Pajer 2002, 357, C1), Hrubá Vrbka 1360 (MZD I, 35 č. 702). V rámci panství veselského, kde je situace s písemnými prameny obdobná, jde o Hroznovou Lhotu vzpomínanou v roce 1422 (RI XI/1, 164 č. 109) a Tasov, který je sice pravděpodobně zmíněn již v listině z roku 1217, ale další zmínka je až z roku 1358 (MZD I, 27 č. 536). Malá Vrbka, jediná obec jižně od Veličky náležející k veselskému panství, je doložena až v roce 1422 (RI XI/1, 164 č. 109), a to i přesto, že archeologické nálezy jsou známy již z druhé poloviny 13. století. Pokud budeme předpokládat, že námi zkoumaná lokalita vznikla až po roce 1260 , v rámci připojení Strážnicka k českému státu, je vidno, že se nemusela v písemných pramenech vůbec objevit, a to až skoro do poloviny 15 . století. Zde je důležitý fakt, že doposud získaný archeologický materiál je datován do 13. a 14. století, přičemž keramika pokročilého 15. století zde zcela chybí. Vesnice tedy nejspíše zanikla ještě před polovinou 15. století. Historicky by se tato událost snad dala spojit s tažením v listopadu 1421. Tehdy na Moravu vtrhl vojevůdce císaře Zikmunda Lucemburského, Vlach Pipo Spano, aby poplenil a dobyl strážnické panství Petra z Kravař. Míra brutality a destrukce tohoto zásahu pronikla i do tehdejších historických pramenů (Vavřinec z Březové, 269-270 č. 117). Snad v té době mohla být vypleněna a následně opuštěna i námi sledovaná podhorská vesnice. Časný zánik vesnice a dochování pouze pozdních písemných pramenů tak mohl vést $\mathrm{k}$ absenci jakýchkoliv zmínek o této zaniklé vsi.

Samotný název Vojšice, který předpokládáme i pro zdejší zaniklou vesnici, máme doložen také v období raného novověku. První zmínka je v privilegiu vydaném v roce 1580 pro Sebolda Čačka z Hernsdorfu na jeho dvůr v Kněždubu. Je zde uvedeno půldruhého lánu louky ve „Volšicích“, a to ve svobodné držbě (Pajer 2011 a kol., 280, A). Vojšické louky máme znovu doloženy $\mathrm{v}$ roce 1593 . V tomto roce zde přepadli poddaní z Malé Vrbky Jana Kubíčkova z Lipova, který uvádí, že ,ze své louky Vojšické jel“. Poté ho věznili na Uherském Ostrohu, pod nějž v ten čas Malá Vrbka patřila (Dvorský 1914, 385). Další zmínka je z počátku 17. století, kdy Jan Fridrich z Žerotína, majitel strážnického panství, daroval sedm luk na Vojšicích Petrovi Vojskovi, majiteli Veselí. Louky tehdy patřily k Lipovu. Fridrich z Žerotína posléze v roce 1610 tyto louky osvobodil od veškerých dávek (Dvorský 1914, 385). Ze stejného pramene je i doložen plat z další 
louky na Vojšicích k Lipovu. V roce 1605 se krajem prohnali Bočkajovci, kteří způsobili velké škody na všech vsích v okolí. Poškozen byl i svobodný statek Jana Čačka z Herndorfu. Z př́íkazu strážnické vrchnosti došlo v roce 1614 k prodeji opuštěného dvora a mezi př́slušenstvím je znovu zahrada Vojšice (Dvorský 1914, 328). Tentýž majetek je uveden i v roce 1615 v privilegiu pro Reytena z Varjelit a znovu v roce 1618 (Pajer 2011 a kol., 284, D; 288, F). Louka je vždy zmiňována př́mo jako svobodná držba, jednalo se tedy nejspíše zároveň i o dominikální půdu. Jako „louky Vojšice Lipovská“ jsou pak zmiňovány v roce 1775 u Hrubé Vrbky (Pavlík 2011, 234). Z roku 1794 známe Vojšické louky a konec Vojšického potoka z map moravsko-uherského pohraničí, které byly vytvořeny při řešení pohraničního sporu v prostoru Dlhé Lúčky a vrchu Žalostiné (Pajer 2002, 273-275).

\section{Polní tratě}

Pro jasnou a přehlednou orientaci v textu je nezbytné si jasně definovat jména polních tratí, na kterých se nacházejí identifikované terénní relikty a byl na nich prováděn geologický, palynologický, geofyzikální a archeologický průzkum. Pomístní jména byla převzata ze stabilního katastru. V př́ípadě duplicit je jméno polní tratě doplněno novým názvem z aktuálních katastrálních map, map SMO-5 nebo základní mapy ZM10.

Dnešní pojmenování tratí na mapách je až na některé drobné změny stejné jako na počátku 19. století. Nové jsou tratové názvy U Zbrodku, Dubníky a Veselské. V př́ípadě západního umístění trat'ového názvu U Zbrodku tam, kde přechází stará cesta přes Radějovku, jde o název, který byl již použit v odborné literatuře (Snášil 1973, 108). Tratě Dubníky a Veselské, se kterými se setkáváme na mapách dnes, jsou bud' zcela nové nebo na mapě špatně umístěné (např. Dubníky).

Celé vymezené území projektu patří z administrativního hlediska do katastru několika obcí: Hrubé Vrbky, Malé Vrbky, Radějova, Hroznové Lhoty, Tasova a Kněždubu (obr. 1). Prostor vesnice a sledovaných terénních reliktů náleží pouze katastrům Hrubé Vrbky a Kněždubu. Tyto dva katastry budou základem pojmenování tratě ve všech př́ípadech, at' už je název originální, nebo se opakuje. Hlavní osou analyzovaného území je říčka Radějovka, která pramení v jeho jižní části a teče přímo severním směrem. Pravobřeží říčky, tratě Rubanice a Vojšice, náleží administrativně k Hrubé Vrbce.

\section{Analýza digitálního výškopisu}

K analýze byla použita data digitálního výškopisu České republiky, která jsou distribuována ČÚZK pro badatelské projekty jako surová data - ground. Jedná se o zobrazení území o rozloze $20 \mathrm{~km}^{2}$ sestávající ze čtyř mapových listů SM-O 5. Část vymezeného území náleží Slovenské republice, kde nebylo laserové skenování provedeno v národním ani lokálním měřítku. Letecké skenování bylo realizováno v dubnu 2013 v době, kdy nebyly křoviny ani stromy ještě olistěny. Na metr čtvereční připadá průměrně 1,5 bodu. Model je distribuován jako XYZ textový soubor, který byl převeden do rastrové podoby pomocí interpolační funkce NATURAL NEIGHBOUR při velikosti rastrové buňky $1 \mathrm{~m}$.

Data byla po interpolaci zpracována jednak nástrojem HILLSHADE, který byl trojnásobně převýšen, přičemž nastavení azimutu a elevace zdroje světla bylo po několika pokusech s jinými hodnotami ponecháno na základních parametrech ( $315^{\circ}$ azimut, $30^{\circ}$ elevation), a jednak nástrojem LOCAL RELIEF MODEL. Viditelné liniové útvary byly ručně vektorizovány do samostatných vrstev. Jedná se o polní komunikace, vějíře úvozových cest a vyvýšené liniové útvary jdoucí po vrstevnici nebo po svážnici interpretované jako možné zbytky mezí. Jako plošná vrstva byla definována soustava výsledků místního geologického jevu - sesuvů, které jsou pro západní stranu čertoryjského kopce charakteristické.

$\mathrm{K}$ identifikaci a př́ípadné dataci liniových útvarů byla využita historická data. Jedná se o tzv. císařské povinné otisky stabilního katastru, které byly vektorizovány a doplněny o informace o vlastníkovi pozemku z listů stabilního katastru, který je volně k dispozici na stránkách 
Moravského zemského archivu. Nejstarší zachycený stav majetkových poměrů na lokalitě byl konfrontován s nejnovějším stavem hranic parcel katastrálních map pomocí wms připojení poskytovaných ČÚZK. Topografické informace (vodní toky, komunikace, stavby, landuse) byly také odvozeny z povinných otisků. Byly konfrontovány všechny dostupné mapové archiválie publikované na stránkách ČÚZK.
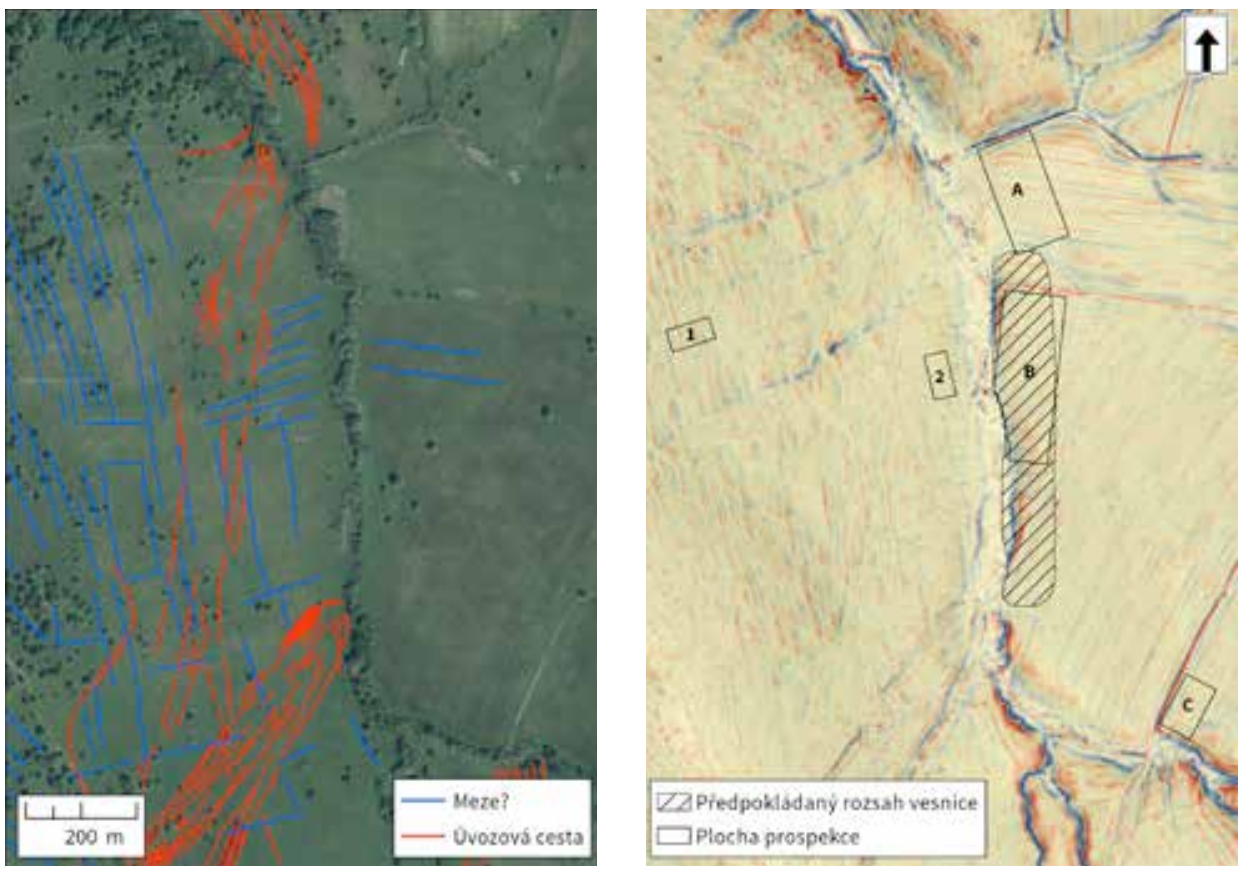

Obr. 2. Vlevo: Vektorizované pozůstatky mezí a pravděpodobných úvozových cest. Vpravo: Data digitálního vy̌škopisného modelu zpracovaná nástrojem LOCAL MODEL RELIEF s vyznačenými plochami geofyzikální prospekce a předpokládaným rozsahem ZSV Vojšice. Podle Snášil 1973, 109.

Abb. 2. Links: Vektorisierte Überreste von Flurgrenzen und wahrscheinlichen Hohlwegen. Rechts: Die Daten des digitalen Höhenmodells wurden mit dem Visualisierungswerkzeug LOCAL MODEL RELIEF unter Einzeichnung der geophysikalischen Prospektionsflächen und der angenommenen Ausdehnung der mittelalterlichen Dorfwüstung Vojšice verarbeitet. Nach Snášil 1973, 109.

\section{Geofyzikální prospekce}

Nejvhodnější geofyzikální metodou pro průzkum sídlištních areálů v extravilánu je magnetometrie. Tato nedestruktivní metoda umožňuje efektivní a rychlou detekci a identifikaci sídlištních a jiných struktur na rozsáhlé ploše (Dresler-Tencer-Vágner 2015; Milo 2009; 2013; 2014). Podstatou metody je měření intenzity magnetického pole Země, v jehož rámci jsou zaznamenávány lokální anomálie. Vznik těchto anomálií je spojován s př́ítomností podpovrchových struktur různého, především však geologického, pedologického nebo antropogenního původu. Mezi antropogenní struktury patř́ i archeologické objekty.

Základním předpokladem $\mathrm{k}$ úspěšné identifikaci těchto struktur je jejich dostatečný kontrast vůči podloží, resp. vůči jejich bezprostřednímu okolí. Nejdůležitější ovšem nejsou absolutní hodnoty magnetického pole, ale právě rozdíl mezi hodnotami zásypů objektů a jejich okolí. Kromě výrazné výplně a tvaru objektu je při archeologické interpretaci geofyzikálních dat velice důležitým faktorem samotný rozsah prozkoumané plochy. Jenom dostatečně plošně rozsáhlý 
průzkum může zodpovědět otázky související s rozsahem osídlení a jeho intenzitou nebo s charakterem antropogenní činnosti na zkoumaném místě (Křivánek 2004, kap. 4.4).

Ke geofyzikální prospekci byly použity fluxgate magnetometry LEA MAX (Eastern Atlas, Německo) s deseti sondami a FOERSTER FEREX 4.032 DLG (Foerster, Německo) se čtyřmi sondami, oba s ručním vozíkem.

Přístroje jsou konstruované jako gradiometry na měření rozdílů vertikálních prvků magnetického pole ve dvou odlišných výškách od povrchu. U obou magnetometrů byly použity sondy FEREX CON 650 s vertikální vzdálenosti mezi dvěma senzory v každé sondě $0,65 \mathrm{~m}$. Horizontální vzdálenost mezi sondami byla stanovena na $0,5 \mathrm{~m}$. Př́stroje umožňují kontinuální měření hodnoty změny intenzity magnetického pole s přesností $0,2 \mathrm{nT} / \mathrm{m}$, a to ve frekvenci několik desítek měření za sekundu. Měření bylo provedeno v manuálním módu v síti $0,25 \times 0,50 \mathrm{~m}$, a to $\mathrm{v}$ předem vytyčených polygonech. Rohy jednotlivých polygonů byly vytyčeny za pomoci geodetického RTK GNSS př́stroje Leica Viva GS15.

Data z měření byla spravovaná standardním postupem v programu LEAD2. Mapa změny magnetické intenzity magnetického pole (magnetogram) v nanoteslách (nT) byla následně vyhlazena průměrovacím filtrem. Pro účely prezentace a interpretace výsledků byl použit software ArcGIS Desktop 10.3 (ESRI).

Geofyzikální průzkum se uskutečnil ve dvou etapách. Plochy na levém břehu Radějovky byly měřeny na podzim 2015. Během jara následujícího roku byly změřeny plochy na pravém břehu vodoteče. Plochy na pravém břehu Radějovky byly zvoleny jednak na základě předešlých povrchových průzkumů a doporučení místního amatérského archeologa, jednak na základě analýzy dat digitálního výškopisu České republiky.

Dvě menší plochy na levém břehu Radějovky byly vybrány na základě analýzy dat digitálního výškopisu. Polygony, každý o rozměrech $40 \times 80 \mathrm{~m}(0,32 \mathrm{ha})$, byly situovány v místech průběhu nově objevených vyvýšených liniových útvarů. Na ploše 1 byla mimo magnetometrie použita i metoda pozemního georadaru (aparatura X3M Ramac a dvě odstíněné antény o centrální frekvenci 250 a $500 \mathrm{MHz}$, MALÅ, Švédsko). V místech prospekce se však touto metodou nepodařilo zachytit žádné výraznější anomálie.

\section{Interpretace geofyzikálních dat}

Cílem geofyzikální prospekce bylo identifikovat potenciální archeologické objekty na zkoumaném území, především ale struktury, které by mohly indikovat ZSV Vojšice. V případě prospekce plochy (1 a 2) na levém břehu Radějovky byla cílem verifikace/prozkoumání liniových struktur identifikovaných na digitálním výškopisném modelu (obr. 2).

Prospekce odhalila řadu anomálií, u nichž je možno předpokládat, že souvisí s antropogenní činností na lokalitě. Anomálie s převažujícími kladnými hodnotami změny intenzity magnetického pole jsou nejčastěji interpretovány jako zahloubené archeologické objekty - jámy. Negativní anomálie často reprezentují struktury či objekty obsahující kamenné prvky - zdivo. Anomálie s výraznou kladnou i zápornou složkou nazýváme bipolárními. Tyto často poukazují na př́ítomnost ferrimagnetických materiálů - kusů železa nebo přepálených struktur - pecí.

Na magnetogramu první plochy (1) na levém břehu Radějovky jsou patrné tři nevýrazné liniové struktury o délce 40 metrů a šířce zhruba 4 metry. Vzdálenost mezi jednotlivými liniemi je 20 , resp. $30 \mathrm{~m}$. Jedná se o magneticky nevýrazné anomálie (kolem $1 \mathrm{nT}$ ) jdoucí po vrstevnici. Díky jejich korelaci s topografickými prvky na digitálním výškopisu a dostatečnému plošnému rozsahu prospekce je možno tyto prvky interpretovat jako relikty mezí (obr. 3).

Na druhé ploše (2), ležící na levém břehu, se nachází několik anomálií (4-6 nT), které lze interpretovat jako archeologické objekty - sídlištní jámy. Vzhledem k tomu, že tato část břehu nebyla dostatečně prozkoumána, nemůžeme objekty blíže interpretovat. Není vyloučeno, že se jedná o objekty související se ZSV Vojšice. Na magnetogramu je v okolí identifikovaných anomálií - objektů - možno pozorovat několik nehomonogenit, bez ostrých hranic. Tyto mohou 

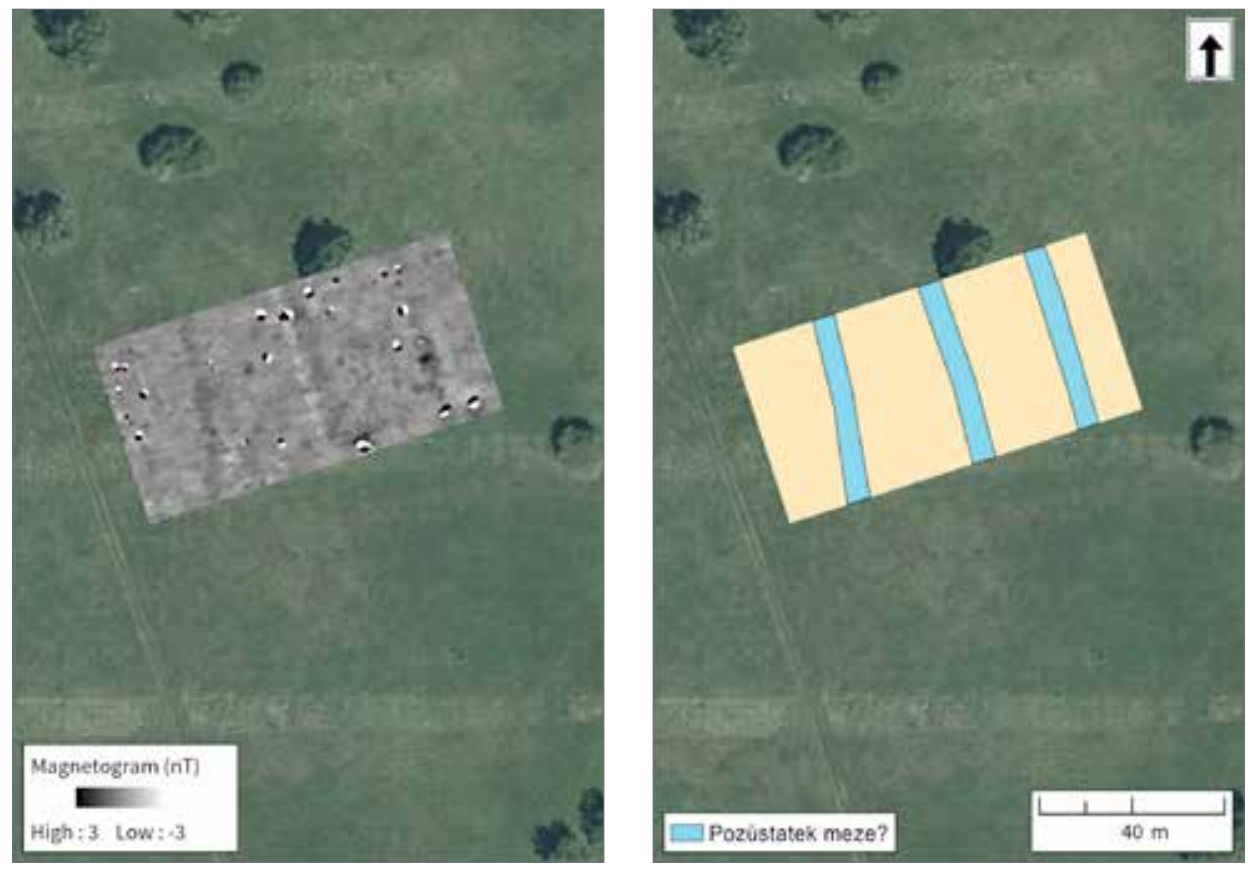

Obr. 3. Výsledky geofyzikální prospekce plochy 1 situované na levém břehu Radějovky. Vlevo magnetogram; vpravo interpretace magnetometru. Autoři Tomáš Tencer, Peter Milo a Michal Vágner.

Abb. 3. Ergebnisse der geophysikalischen Prospektion der am linken Ufer des Baches Radějovka gelegenen Fläche 1. Links Magnetogramm; rechts Interpretation des Magnetometers. Erstellt von Tomáš Tencer, Peter Milo und Michal Vágner.

představovat další - menší - nezachycené archeologické objekty, jejichž bližšśi interpretace je rovněž nemožná (obr. 4).

První plocha (A) na pravém břehu o výměře 2 ha byla umístěna při soutoku Radějovky s bezejmennou vodotečí, severně od předpokládaného okraje ZSV. Na ploše jsme identifikovali několik pozitivních anomálií ( 3 až $9 \mathrm{nT}$ ). Počet anomálií roste směrem k říčce Radějovka a směrem k jihu. Anomálie však netvoří žádné výrazné koncentrace a jejich interpretace jako sídlištní objekty je sporná, i když možná. Obzvláště u jižního okraje plochy se může jednat o okraj ZSV. Tuto domněnku podporuje i existence výrazných bipolárních anomálií, které je možno interpretovat jako objekty - pyrotechnická zařízení či výrobní objekty - související s činností ohně $(-10 \mathrm{nT}$ až $60 \mathrm{nT})$. Na magnetogramu jsou dále vidět linie kolmé na vodoteč. Jedná se pravděpodobně o stopy po technice nebo zemědělské činnosti (obr. 5).

Druhá plocha (B) o výměře 3 ha byla situována podélně $\mathrm{s}$ Radějovkou, $\mathrm{v}$ místech, kde by se podle dostupných informací měla nacházet ZSV Vojšice. Na magnetogramu měřené plochy se nachází množství anomálií - objektů, které zřetelně dokládají sídelní aktivitu. V pásu táhnoucím se podél toku Radějovky v šířce 40-60 metrů je možno sledovat minimálně pět koncentrací anomálií, resp. nehomogenit. Širokému spektru zachycených anomálií dominují čtyři výrazné bipolární anomálie. Díky jejich poloze (nacházejí se stranou od ostatních anomálií) a na základě naměřených hodnot (-20 nT až $60 \mathrm{nT}$ ) můžeme tyto anomálie interpretovat jako pyrotechnická zařízení, resp. objekty spojené s použitím ohně. Zbylé - pozitivní - anomálie je možno interpretovat jako zahloubené objekty. Koncentrace jsou rozměrově srovnatelné (přibližně $15 \times 40 \mathrm{~m}$ ), mají i stejnou orientaci (kolmo na vodoteč) a v jejich blízkosti se nachází minimálně jedna výrazná bipolární anomálie - pec. V rámci některých koncentrací se nachází další, méně výrazné bipolární anomálie. Tyto mohou představovat přepálené objekty nebo menší pyrotechnická 

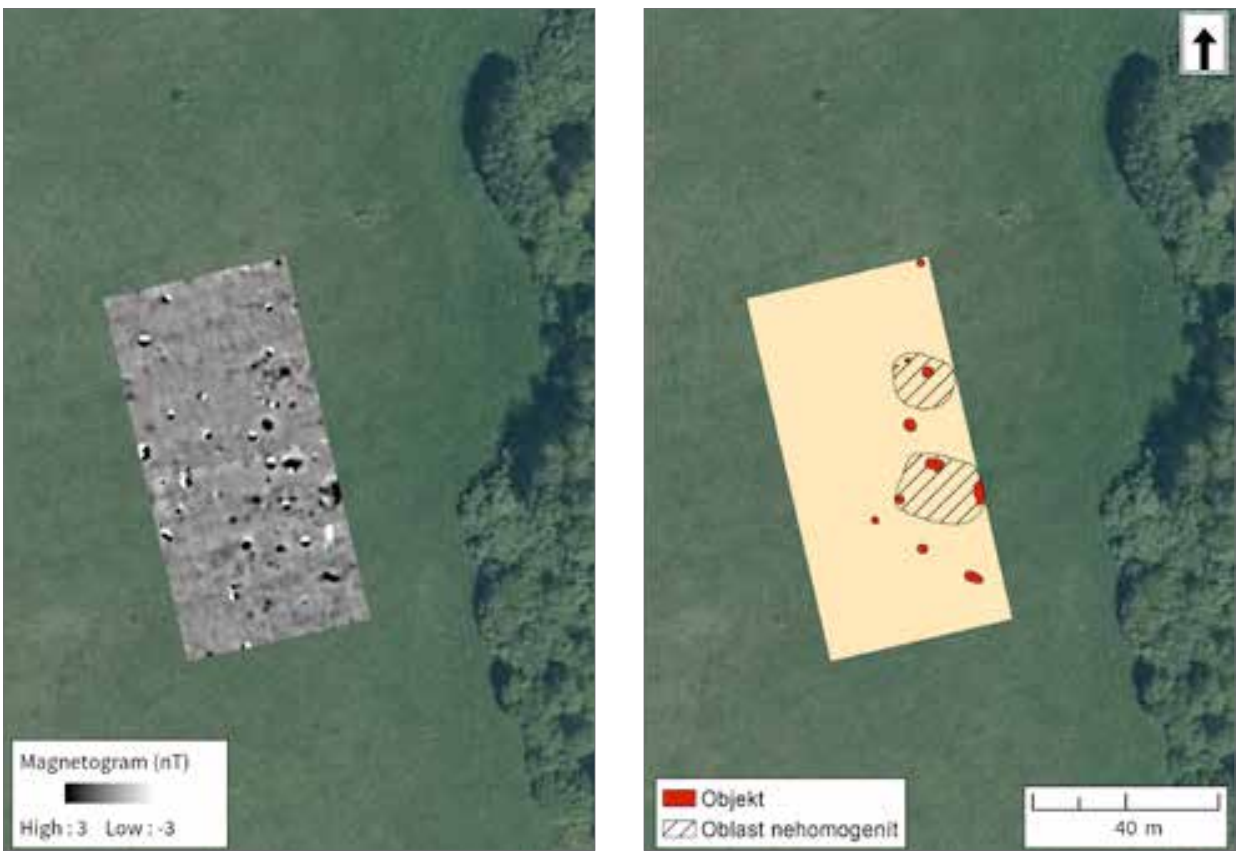

Obr. 4. Výsledky geofyzikální prospekce plochy 2 situované na levém břehu Radějovky. Vlevo magnetogram; vpravo interpretace magnetometru. Autoři Tomáš Tencer, Peter Milo a Michal Vágner.

Abb. 4. Ergebnisse der geophysikalischen Prospektion der am linken Ufer des Baches Radějovka gelegenen Fläche 2. Links Magnetogramm; rechts Interpretation des Magnetometers. Erstellt von Tomáš Tencer, Peter Milo und Michal Vágner.
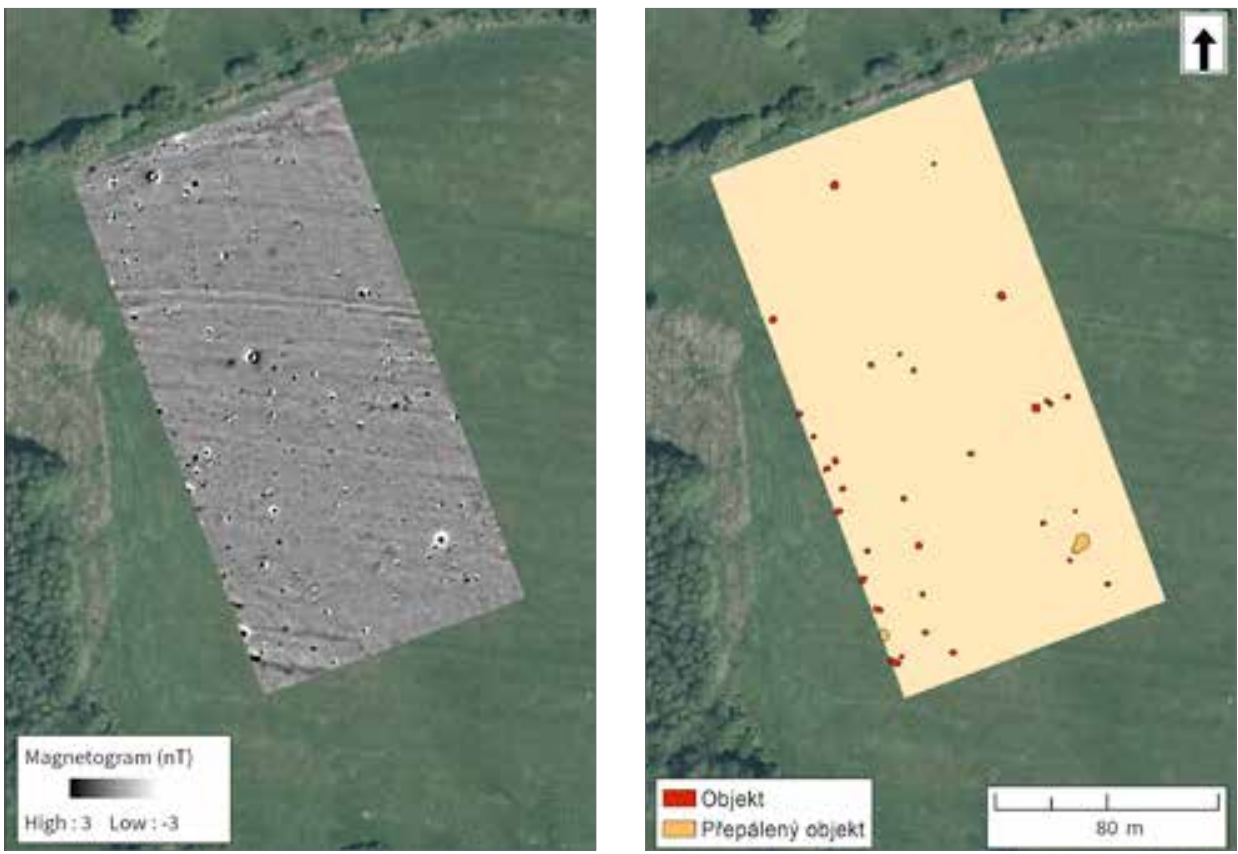

Obr. 5. Výsledky geofyzikální prospekce plochy A situované severně od ZSV Vojšice. Vlevo magnetogram; vpravo interpretace magnetometru. Autoři Tomáš Tencer, Peter Milo a Michal Vágner.

Abb. 5. Ergebnisse der geophysikalischen Prospektion der nördlich der mittelalterlichen Dorfwüstung Vojšice gelegenen Fläche A. Links Magnetogramm; rechts Interpretation des Magnetometers. Erstellt von Tomáš Tencer, Peter Milo und Michal Vágner. 
zařízení - otopná či výrobní zařízení. Na základě dostupných informací lze tak tyto shluky anomálií interpretovat jako zbytky jednotlivých usedlostí (obr. 6).

U jižního okraje plochy jsme detekovali dvojici magneticky pozitivních liniových anomálií v délce 23 , resp. $30 \mathrm{~m}$. Obě linie jsou široké $1 \mathrm{~m}$ a jsou od sebe vzdáleny přibližně $10 \mathrm{~m}$. Linie jsou kolmé na svah a připomínají relikty mezí zachycených na levém břehu Radějovky. Identifikaci dalších podobných linií na ploše komplikuje výrazný opakující se vzor linií ve směru severovýchod-jihozápad. Tyto jsou výsledkem zemědělské činnosti z minulého století - orby (obr. 6).

Třetí plocha (C) o výměře 0,6 ha byla umístěna asi 500 m jihovýchodním směrem od ZSV, v blízkosti bezejmenné vodoteče, kde M. Ďuga nalezl při povrchovém sběru raně středověkou sekeru. Prospekci na ploše komplikovala př́ítomnost mladých ovocných stromků a jejich pletivová ochrana proti okusu zvěří. Velké množství recentního materiálu, který se nacházel př́mo na ploše, se však podařilo před prospekcí odstranit. Je ale pravděpodobné, že drobný recentní magnetický materiál/odpad zůstal ve svrchní vrstvě půdy, kde nadále narušoval magnetické pole. Kromě recentního rušení se na ploše nachází několik pozitivních anomálií, které mohou souviset $\mathrm{s}$ antropogenní činností. V tomto př́ípadě se opět může jednat o zahloubené objekty - sídlištní jámy bez bližší funkční specifikace. Drobné bipolární anomálie jsou kromě dvou menších koncentrací rozmístěny rovnoměrně. Tyto anomálie často představují zbytky kovových předmětů, at' už archeologického, nebo recentního stáří (viz nález sekery). Zmíněné koncentrace by mohly indikovat hroby nebo pohřebiště. Může se však jednat pouze o recentní materiál související s oplocenkami. Vzhledem ke kontaminaci plochy recentními prvky může jistotu v této otázce přinést pouze archeologický výzkum (obr. 7).

Na většině měřených ploch se nachází množství drobných bipolárních anomálií. Tyto jsou často interpretovány jako drobné kovové předměty či magnetické horniny ležící na, anebo těsně
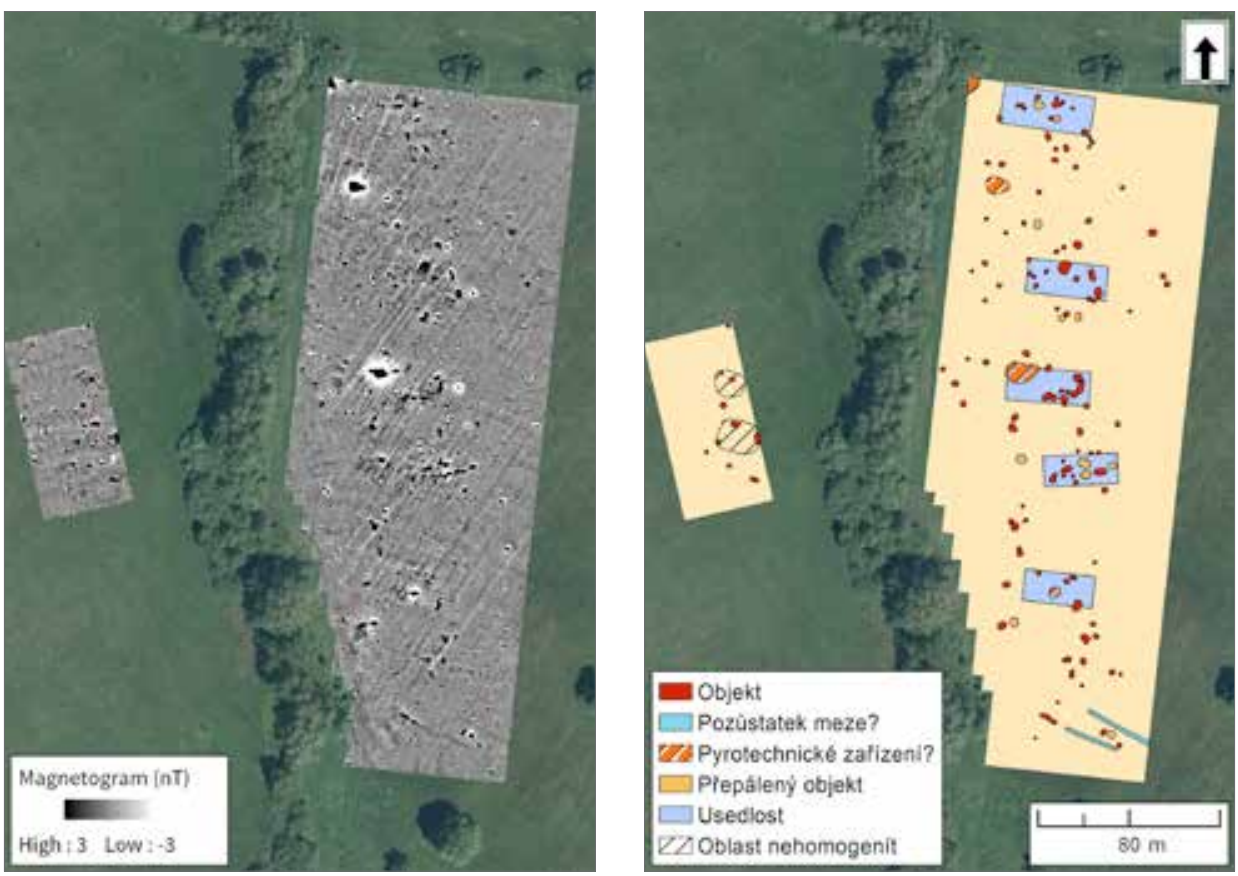

Obr. 6. Výsledky geofyzikální prospekce plochy B situované na ploše ZSV Vojšice. Vlevo magnetogram; vpravo interpretace magnetometru. Autoři Tomáš Tencer, Peter Milo a Michal Vágner.

Abb. 6. Ergebnisse der geophysikalischen Prospektion der auf der Fläche der mittelalterlichen Dorfwüstung Vojšice liegenden Fläche B. Links Magnetogramm; rechts Interpretation des Magnetometers. Erstellt von Tomáš Tencer, Peter Milo und Michal Vágner. 

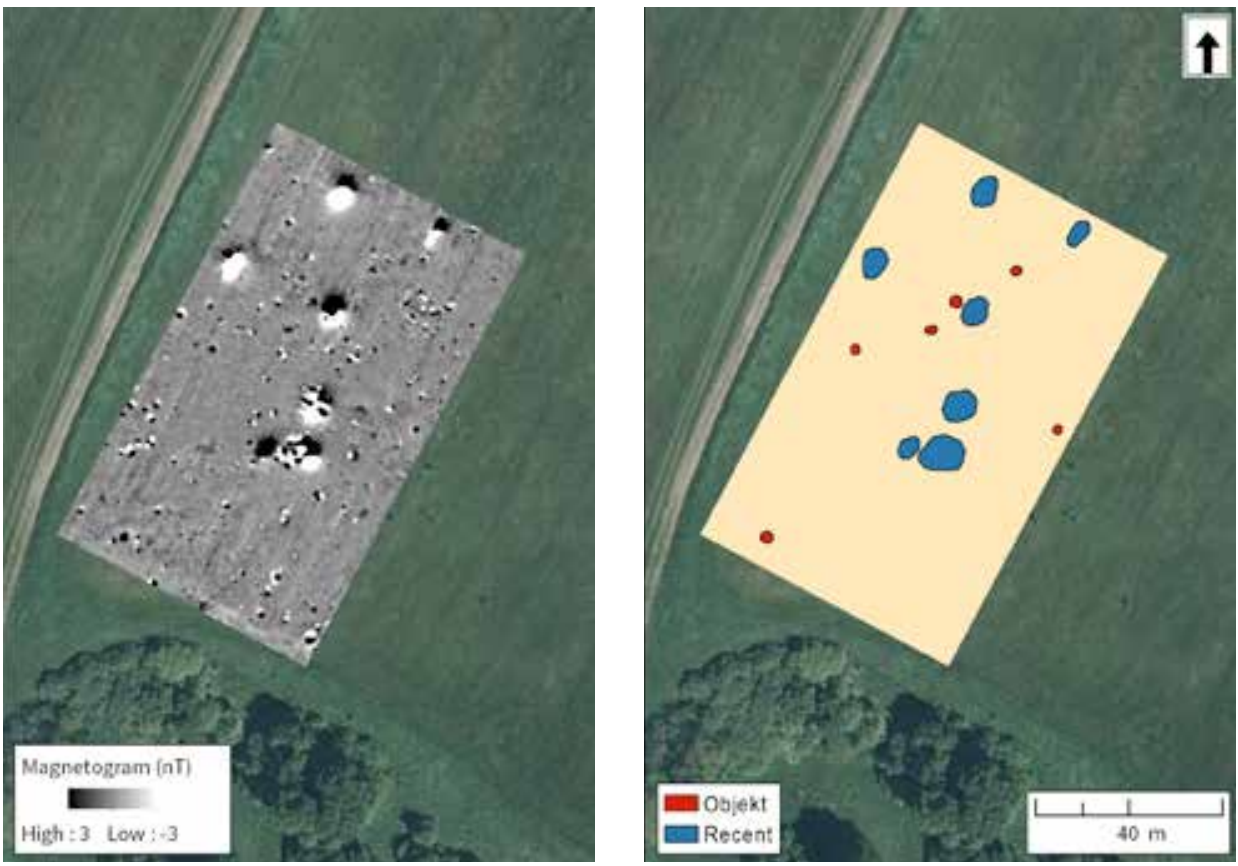

Obr. 7. Výsledky geofyzikální prospekce plochy C situované jihovýchodním směrem od ZSV Vojšice. Vlevo magnetogram; vpravo interpretace magnetometru. Autoři Tomáš Tencer, Peter Milo a Michal Vágner.

Abb. 7. Ergebnisse der geophysikalischen Prospektion der südöstlich der mittelalterlichen Dorfwüstung Vojšice gelegenen Fläche C. Links Magnetogramm; rechts Interpretation des Magnetometers. Erstellt von Tomáš Tencer, Peter Milo und Michal Vágner.

pod povrchem. Jejich stáří nelze bezpečně určit. Může se jednat o předměty archeologického, ale rovněž i recentního stáří. Tyto prvky spolu s recentními stopami po technice nebo orbě jsou nedílnou součástí magnetického obrazu krajiny. Jejich př́tomnost mnohdy komplikuje interpretaci archeologických situací, na druhé straně jsou ukazatelem „narušenosti““ archeologických situací, at' už moderním hospodařením, nebo erozí.

\section{Katastr a polnosti vesnice}

Na výškopisném digitálním modelu z roku 2013 byly zachyceny liniové útvary, které jsme zpočátku interpretovali jako meze zaniklé středověké vesnice. Abychom mohli bezpečně tyto útvary přiřadit ke stř̌edověké vesnici, po které se mimo archeologických objektů zachoval pouze trat’ový název „Vojšice“, bylo také nezbytné zpracovat indikační skice a povinné otisky císařských listů, které zachycují pozemkovou držbu a parcelaci z počátku 19. století.

Celý katastr původní vesnice lze rekonstruovat jen stěží. Poměrně jasno máme v případě těch částí Vojšic, které přripadly Hrubé Vrbce a Kněždubu (obr. 8). Katastrální území Hrubé Vrbky bylo rozšiřreno o pravou část Vojšic a luční a lesní polohy směrem k dnešní státní hranici. Tato poněkud nelogická vazba dává smysl, pokud zohledníme fakt, že na rozdíl od Hrubé Vrbky se Vojšicím bližší Malá Vrbka nacházela na sousedním veselském a posléze ostrožském panství. $\mathrm{Z}$ tohoto důvodu nemohla být, jako patrně strážnický majetek, $\mathrm{k}$ ní připojena. Tratě na povinných císařských otiscích jsou zde jen dvě: Vojšice, několikrát se opakující, a Rubanice. Prostor NPR Čertoryje a jižní svahy pod Šumárníkem připadly Kněždubu. Zda území Tvarožné Lhoty bylo 


\begin{tabular}{|l|c|c|c|}
\hline ZSO & Plocha plužiny (ha) & Počet usedlostí & ha na usedlost \\
\hline Ovčinec & 49 & 14 & 3,5 \\
\hline Hrádek & 54 & 13 & 4,2 \\
\hline Schreynern & 83 & 7 & 11,9 \\
\hline Bohdalůvka & 107 & 14 & 7,6 \\
\hline Svatonůvka & 148 & $?$ & 9,0 \\
\hline Vilémov & 199 & 22 & 4,5 \\
\hline Bystřec & 99 & 11 & 88,8 \\
\hline Pfaffenschlag & 120 & 10 & \\
\hline Vojšice & 888 & & \\
\hline Dnešní obce & & & \\
\hline Hrubá Vrbka bez Vojšic & 822 & & \\
\hline Kněždub bez Vojšic & 1208 & & \\
\hline Malá Vrbka & 444 & & \\
\hline Tasov & 638 & & \\
\hline Hroznová Lhota & 903 & & \\
\hline Tvarožná Lhota & 1127 & & \\
\hline Radějov & 2400 & & \\
\hline
\end{tabular}

Tab. 1. Plochy katastrů (katastrálních území) stávajících a zaniklých (rekonstruovaných) vesnic. Tab. 1. Katasterflächen (Katastergebiete) mit bestehenden und wüsten (rekonstruierten) Dörfern.

rozšíř̌eno o původní katastr Vojšic nebo jiné vesnice, není jisté. Protáhlý tvar současného administrativního území by tomu nasvědčoval, stejně jako v případě sousedního Radějova. Nelze vyloučit, že se zde nacházela další, zatím neobjevená osada, snad v údolí potoka Mandát v prostoru tratí Hlavinské, Koutky nebo PR Kútky. Původní katastry obcí Tvarožná Lhota a Kněždub končily zřejmě na hřebenu Šumárníku nebo kousek pod ním, tak jako v př́ípadě hranice mezi dnešní Malou a Hrubou Vrbkou. Katastry Tasova a Hroznové Lhoty nebyly o území Vojšic zřejmě vůbec rozšířeny. Přesto se zdá nepravděpodobné, že by část území, která byla součástí katastru původních Vojšic, připadla k Hroznové Lhotě anebo Tasovu. Důvod je stejný jako v případě Malé Vrbky, která také byla součástí sousedního veselského a později ostrožského panství.

Plochu katastrálního území zaniklých Vojšic v př́ípadě, že byla rozdělena mezi Hrubou Vrbku a Kněždub, odhadujeme na ca 900 hektarů. Což je mnohonásobně větší území, než bylo rekonstruováno pro zaniklé středověké vesnice na Drahanské vrchovině (Černý 1979, 96) nebo např́klad v zaniklém Pfaffenschlagu u Slavonic (Nekuda 1975, 164). Naopak mnohem více se blíži výměře katastrálního území současných okolních vesnic, pochopitelně bez území náležejícího k zaniklé vesnici (viz tab. 1).

Díky geofyzikální prospekci a starší povrchové prospekci víme, že lze Vojšice rekonstruovat jako jednostrannou řadovou ves o minimálně šesti usedlostech. Podle Roberta Snášila vesnice začínala u brodu přes Radějovku a končila v místech soutoku Radějovky s jejím pravostranným přítokem. Na základě povrchové prospekce, sledování nálezů, zbarvení půdy a dalších znaků předpokládá autor délku vesnice $700 \mathrm{~m}$ a její šířku 50-60 m (Snášil 1973, 107109). Geofyzikální prospekcí se podařilo identifikovat pět areálů, které víceméně korespondují 

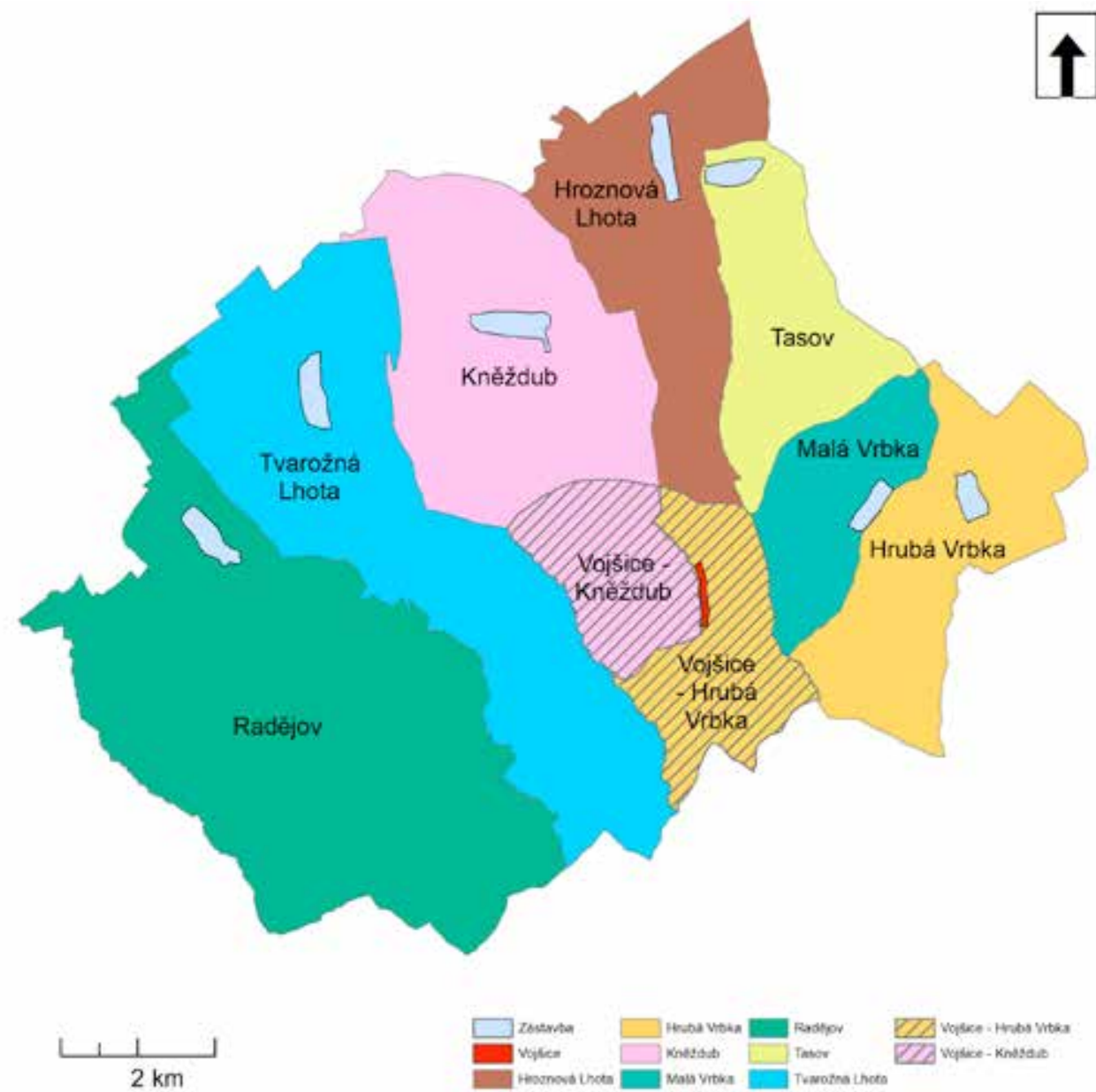

Obr. 8. Rekonstrukce původního katastru ZSV Vojšice - šrafovaně. Autor Petr Dresler.

Abb. 8. Rekonstruktion des ursprünglichen Katasters der mittelalterlichen Dorfwüstung Vojšice - schraffiert. Erstellt von Petr Dresler.

s pozemkovou parcelací, resp. usedlosti 2 a 3 se nacházejí v rámci jedné parcely. Nemůžeme vyloučit, že se původně jednalo o dvě parcely, které byly sloučeny do jedné. Nicméně při pohledu na mapu je zřejmé, že pokud bychom toto členění prostoru přijali jako doklad středověké parcelace, lze jak severním, tak jižním směrem očekávat další usedlosti. Pokud bychom ovšem potvrdili existenci dalších usedlostí i v jižním směru, mohl by jejich celkový počet na lokalitě dosáhnout až dvanácti.

$\mathrm{Z}$ tohoto pohledu potom výrazně vyčnívají rozsáhlé pozemky v prostoru geofyzikálně měřené plochy A. Ta byla na indikační skice z roku 1827 v majetku knížete Jana Lichtenštejna a teprve někdy v 19. století byla rozdělena na menší části. Teoreticky lze uvažovat o tom, že jde o stejnou dominikální půdu, která byla na počátku 17. století jako sedm luk darována Janem Fridrichem z Žerotína majiteli veselského panství Petru Vojskovi z Bogunčovic. Možnost podporuje i informace o držbě Lichtenštejny, kteří pozemek vlastnili jako majitelé ostrožského panství. Bud' byla tato půda osvobozena od všech dávek až na počátku 17. století, nebo se může 
jednat o relikt držby významnější osoby ve vesnici, např́iklad rychtáře. Podobně je dominikální díl zachován i na katastru Kněždubu, kde na indikační skice náleží do strážnického panství Magnisů. Patrně ho také můžeme spojit i s historicky doloženým prodejem majetku svobodného tzv. Raytenova dvora v roce 1614, který je poprvé připomínán již v roce 1583. Majetek dvora se následně po třicetileté válce vrátil do prŕímé držby strážnického panstva. Po celou dobu se jednalo o svobodnou držbu.

Podle dochované parcelace na levém břehu Radějovky (dnes k. ú. Kněždub), starší povrchové prospekce a podle konfigurace terénu se nedomníváme, že by se zde nacházely usedlosti, ale předpokládáme pouze ojedinělé objekty. Některé linie identifikované na digitálním výškopise a po spádnici by mohly být pozůstatkem středověkých plužin. Půdní pokryv je zde ale natolik mocný a bez př́tomnosti kamenů, že zde nelze očekávat jakékoliv výrazné útvary. Díky tomu se středověká parcelace dochovala pouze ve formě hranic pozemkové držby.

Původní pole ale musíme očekávat $\mathrm{v}$ bezprostřední návaznosti na identifikované usedlosti. Napovídá tomu jak konfigurace terénu, tak i členění pozemků. Hranice mezi usedlostmi lze sledovat téměř po hřeben kopce, který tvoří přirozenou hranici mezi dnešní Hrubou a Malou Vrbkou. Ve střední části je sice směr parcel otočen, ale to může být výsledkem až mladších pozemkových úprav při začleňování parcel do katastru Hrubé Vrbky. Parcely na levém břehu mohly být jako pole využívány jen v nejbližší vzdálenosti, tomu by nasvědčovaly identifikované spádnicové linie, které jdou vždy maximálně do poloviny svahu a výrazně narušují vrstevnicové liniové útvary.

\section{Diskuse}

Analýzou dat digitálního výškopisu České republiky se podařilo na obou stranách říčky Radějovky identifikovat vyvýšené liniové terénní útvary, které byly interpretovány jako pozůstatky mezí zaniklých polních systémů neznámého stáří. Zachycené meze se jednak od sebe liší svým průběhem, orientací a rozestupy, jednak se navzájem překrývají, a proto je pravděpodobné, že se jedná o dva, nebo více polních systémů, pravděpodobně náležících do vícero časových období. Několik z těchto terénních útvarů se nachází i v těsné blízkosti zaniklé vesnice Vojšice, a to na obou stranách Radějovky kolmo k vodnímu toku a k delší ose zaniklé vesnice. Při porovnání se všemi dostupnými mapovými archiváliemi vyšlo najevo, že meze, které se nachází na pravém břehu Radějovky, korelují svojí orientací a průběhem s dochovanými parcelami zachycenými na tzv. císařských povinných otiscích stabilního katastru. Na pravém břehu Radějovky naproti zaniklé vsi byly analýzou výškopisných dat identifikovány další stejně orientované meze, z nichž některé se táhnou až $200 \mathrm{~m}$ do svahu.

Západně od ZSV Vojšice byly analýzou výškopisných dat identifikovány zahloubené liniové terénní útvary, které lze interpretovat jako možné pozůstatky úvozových cest. K Radějovce se sbíhají na dvou místech. Jednak u předpokládaného jižního okraje zaniklé vesnice a potom severně od ní. Zachyceny byly pouze na levém břehu Radějovky, na strmějších svazích, s minimální zásahy moderního zemědělství. Otázkou je jejich stáŕí. Je jisté, že jsou dodnes zčásti využívány jako př́ležitostné komunikace. Díky jejich průběhu je však možné, že mají vztah $\mathrm{k}$ zaniklé vesnici. Identifikované cesty jsou v superpozici s vyvýšenými terénními útvary - mezemi, přičemž meze jsou starší. Zachycené svazky úvozových cest tedy jistě nemůžeme považovat například za část tzv. cesty českých stráží doložené v pramenech z 13. století. Ta vedla patrně pouze po okraji vojšických luk (srov. Pajer 2011, 203-214). Identifikovaná komunikace vznikla zřejmě až později. Můžeme uvažovat o tom, že trasa byla součástí cesty směrem na uherské Sobotiště, které již ve středověku plnilo úlohu hraničního přechodu. Cesta ovšem také mohla mít pouze lokální význam. Mohla např́íklad obsluhovat prostor okolo Dlhé Lúky a ostatní pastviny na západním svahu vrchu Žalostiné. Ty, jak víme, byly alespoň po nějaký čas součástí strážnického panství a v polovině 17. století byly předmětem vleklých sporů (srov. Pajer 2002, 385-392). Tak či tak, relikt úvozových cest je patrně raně novověkého stáří. Částečně ovšem nelze vyloučit 
i jeho starší existenci, přičemž využíván byl jistě i v pokročilém novověku a v podstatě až do 20. století.

Na základě poznatků z analýzy výškopisu byla na lokalitě provedena i geofyzikální prospekce za pomoci magnetometru. V první fázi byl průzkum zaměřen na levý břeh Radějovky, kde se nachází převážná většina nově zjištěných mezí. V těchto místech byly magnetometricky prozkoumány dvě plochy. První z nich byla zaměřena na průzkum mezí orientovaných po vrstevnici (plocha 1), druhá plocha na meze jdoucí po svážnici (plocha 2). Pozůstatky mezí se podařilo identifikovat pouze na první ploše, kde byly patrné tři liniové anomálie, jejichž průběh byl totožný s terénními útvary viditelnými na digitálním výškopisném modelu. Na druhé ploše (plocha 2) bylo průzkumem odhaleno pouze několik menších anomálií interpretovaných jako sídlištní objekty a dvě výrazné plošné anomálie neurčitého charakteru. Je pravděpodobné, že objekty souvisejí se zaniklou vsí.

Na protějším břehu Radějovky, v místech zaniklé vesnice Vojšice, se podařilo magnetometricky identifikovat celou řadu výrazných anomálií (plocha B). Většinu z nich lze interpretovat jako pozůstatky běžných zahloubených sídlištních objektů. Dále se magnetometrickou prospekcí podařilo zachytit i výrazně přepálené objekty, které by mohly v těchto místech indikovat přítomnost pyrotechnických zařízení. Ta mohla sloužit kupříkladu jako otopná nebo výrobní zařízení. Identifikované anomálie nejsou na prozkoumané ploše rozmístěny náhodně, ale shlukují se do několika pravidelných skupin, které interpretujeme jako pozůstatky jednotlivých usedlostí. Bezpečně se jich prozatím podařilo identifikovat pět. Zachycené usedlosti jsou orientované delší osou kolmo k toku Radějovky. Stejným směrem a víceméně ve stejných intervalech jsou dodnes orientovány hranice parcel na katastrálních mapách a na císařských povinných otiscích stabilního katastru a indikačních skicách. S usedlostmi víceméně korelují i zachycené dva vyvýšené terénní útvary interpretované jako meze.

Na ploše situované severně od ZSV Vojšice (plocha A) se podařilo magnetometrickou prospekcí identifikovat několik desítek menších anomálií. Ty se koncentrují na jihozápadní straně zkoumané plochy. Interpretovat je lze jako pozůstatky menších sídlištních objektů. V několika prrípadech zde byly zachyceny pravděpodobné pozůstatky po pyrotechnických či jiných výrobních zařízeních souvisejících s ohněm. Směrem na sever se počet zachycených anomálií snižuje.

Jihovýchodně od ZSV Vojšice byla situována třetí geofyzikálně zkoumaná plocha (plocha C). Zde bylo zachyceno pouze několik anomálíi interpretovaných jako sídlištní objekty. Zbylé anomálie byly neurčitého charakteru. Pravděpodobně ale souvisí s recentní činností.

V př́ípadě pozdější parcelace, tak jak ji známe z první poloviny 19. století, je jasné, že případný starší rozvrh se dochoval pouze na dílu náležejícím dnes k Hrubé Vrbce. Ovšem i na kněždubské části můžeme snad uvažovat o tradici pozemku v 16. a 17. století, který prŕslušel k tzv. Raytenovu dvoru a který byl později doložen v rukou strážnické vrchnosti. Jak v př́padě výše popsaného pozemku, tak i $\mathrm{v}$ případě dílu na hrubeckém katastru, který později náležel Lichtenštejnům, se jednalo o svobodnou držbu. Můžeme se tedy ptát, zda nešlo o pozůstatek většího majetku, který lze spojit například s rychtářem či lokátorem vesnice. Pokud bychom ovšem přijali interpretaci Žižkova stolu jako drobného středověkého opevněného sídla, mohlo by se jednat i o majetky k němu náležející. Další možnost je ta, že se jednoduše jednalo o šlechtický či např́iklad i církevní majetek, který se ve vesnici pouze nacházel. Jak jsme dovodili, již v roce 1827 doložené rozdělení katastru bývalých Vojšic mezi Kněždub a Hrubou Vrbku je způsobeno rozdílnou příslušností okolních vsí k strážnickému a veselskému, resp. později ostrožskému panství. Nicméně velice zajímavou informací je fakt, že pokud známe starší majetkové poměry a majitele, případně nájemce na hrubecké části, vždy se jednalo o obyvatele Lipova. Bohužel torzovité písemné prameny nedovolují tuto situaci uspokojivě objasnit. Můžeme ale hypoteticky předpokládat, že ještě v roce 1412 tvořily užší součást strážnického panství pouze vesnice Petrov, Rohatec, Sudoměřice, Radějov a Lidéřovice, přičemž nemáme zpráv o existenci Tvarožné Lhoty a Kněždubu. Naopak Tasov, Lipov a Louka byly původně v držení drobné šlechty, stejně jako Hrubá Vrbka, která byla ovšem původně zeměpanská a byla udělována v léno. Drobné šlechtě patřila původně i většina vsí východně od námi zkoumaného prostoru. Ve světle těchto 


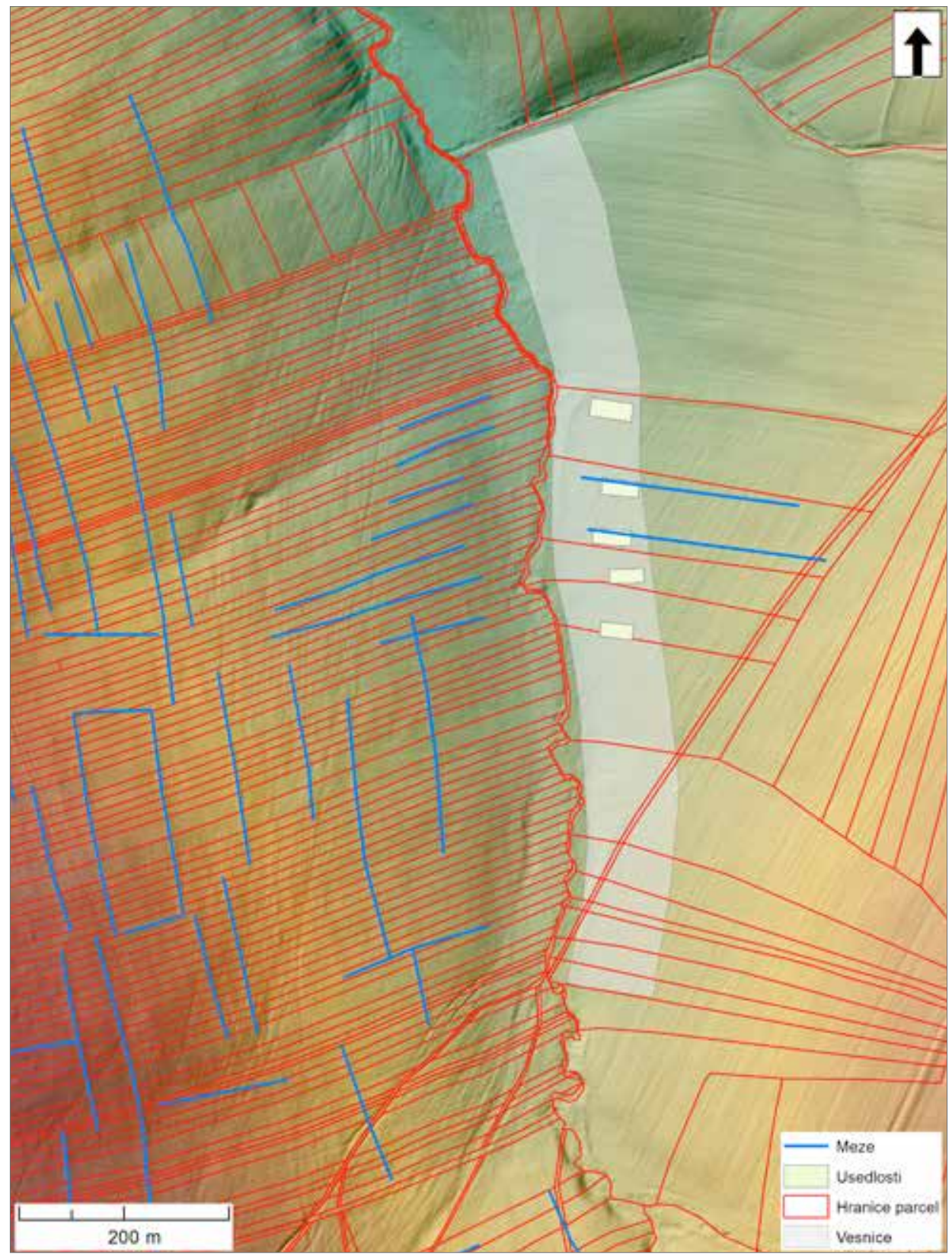

Obr. 9. Hranice parcel podle císařských povinných otisků a indikačních skic stabilního katastru Čech, Moravy a Slezska. Zdroj ČÚZK, upravil Petr Dresler.

Abb. 9. Parzellengrenze gemäß den kaiserlichen Pflichtabdrücken und Indikationsskizzen des Stabilen Katasters von Böhmen, Mähren und Schlesien. Quelle Tschechisches Amt für Landesvermessung und Kataster, bearbeitet von Petr Dresler. 
indicií si lze klást otázku, zda původně Vojšice, stejně jako Tasov, Lipov a Louka a hypoteticky Tvarožná Lhota a Kněždub, nebyly také v držení nižší šlechty. V druhé polovině 14. století pak došlo $\mathrm{k}$ majetkovým přesunům a jednotlivé vesnice byly postupně připojovány $\mathrm{k}$ strážnickému panství. Městečko Velká v roce 1370 (CDM X, 115 č. 94), Lipov v roce 1379 (MZD I, 120 č. 559) a Hrubá Vrbka definitivně v roce 1384 (MZD I, 153 č. 553). Za organickou součást strážnického panství byla tato připojená východní část považována až později. Nicméně právě majetkové napojení části zaniklých Vojšic na Lipov by pak mohlo naznačovat původní držení Vojšic vladyky z Lipova, ještě před připojením k strážnickému panství. $Z$ obecného pohledu pak zánik drobné držby, ke kterému v podhůří Bílých Karpat došlo na úkor scelování velkých panství v druhé polovině 14. století, není jev v zemském měřítku izolovaný, ale pro tehdejší společnost typický.

Pokud se vrátíme zpět k samotným Vojšicím, jednou z nejdůležitějších otázek je samozřejmě datace zachycených komponent. Nejstarší vrstvu snad představují samotné objekty zaniklé vesnice. Ty jsou dostupnými či publikovanými nálezy datovány do období pokročilé druhé poloviny 13. století a do 14. století. R. Snášilem uváděná datace i do 12. století (Snášil 1972, 107-109) nemá oporu v pramenech a stejný soubor datoval Z. Měřínský jasně do 13.-14. století (Měřínský 1974, 76-77).

Patrně středověké pak mohou do velké míry být i veškeré zachycené terasovité úpravy. Pokud tedy vyloučíme pro naši oblast dosud nedoloženou, avšak vzhledem k okolnímu osídlení možnou variantu pravěkého stáří některých mezí. K tomu, že tyto terasy/meze vznikly nejpozději ještě za existence vesnice, nás vede fakt, že veškeré polnosti v trati Vojšice jsou vedeny ve všech dostupných písemných a kartografických pramenech jako louky, a to nejpozději od konce 16. století. Je logické, že takto pracná úprava obyčejných luk, pokud by se nejednalo o pole, pozbývá smyslu. Naopak poměrně strmý svah východního úbočí Čertoryje musel být pro potřeby rostlinné výroby upraven.

\section{Závěr}

Díky kombinaci metod dálkového průzkumu Země, studiu historických pramenů a geofyzikální prospekci se podařilo v okolí ZSV Vojšice identifikovat nejméně dva na sobě nezávislé polní systémy, z nichž jeden lze na základě dostupných poznatků dát do souvislosti se zaniklou středověkou vsí. Zajímavým zjištěním je i tradice v udržení hranic jednotlivých parcel až do dnešních dnů a návaznost katastrálního členění na starší středověkou a raně novověkou majetkovou situaci. Podle konfigurace terénu je zřejmé, že polnosti náležející k vesnici se nacházely na pravém břehu Radějovky, který je co do svažitosti mírnější. Strmý levý břeh byl využíán asi jen ojediněle nebo jen do určité vzdálenosti a od raného novověku spíše jen k pastvě. Pravý břeh byl bohužel po dlouhých dvacet let intenzivně orán moderními zemědělskými prostředky, které setřely starší stopy po osídlení a také výrazně narušily samotné pozůstatky zaniklé vsi, kterou lze datovat pouze do druhé poloviny 13. a průběhu 14. století. Dataci a vznik druhého systému není zatím možné řešit bez intenzivní spolupráce s prŕírodovědnými obory a systematického výzkumu.

Studie byla vytvořena v rámci projektu specifického výzkumu MUNI/A/0930/2018 „Archeologické terénní prospekce, exkavace, dokumentace a muzejní prezentace VIII“.

\section{Prameny a literatura}

CDB V/3: Codex diplomaticus et epistolaris regni Bohemiae V/3. 1253-1278 (Šebánek, J.-Dušková, S., edd.). Pragae 1982. 
CDM V: Codex diplomaticus et epistolaris Moraviae V. 1294-1306 (Chytil, J., ed.). Brunae 1850.

CDM X: Codex diplomaticus et epistolaris Moraviae X. 1367-1375 (Brandl, V., ed.). Brünn 1878.

CDS1 I: Codex diplomaticus et epistolaris Slovaciae I. 805-1235 (Marsina, R., ed.). Bratislavae 1971.

ČERNÝ, E., 1979: Zaniklé středověké osady a jejich plužiny. Praha.

ČERVINKA, I. L., 1931: Pusté vsi. Rkp. ulož. v Moravském zemském muzeu.

DRESLER, P.-TENCER, T.-VÁGNER, M., 2015: Prospekce zaniklé středověké vesnice Opatovice, k. ú. Hrušky - A Survey of the Deserted Medieval Village of Opatovice, Cadastral District of Hrušky, Studia archaeologica Brunensia E 20, 113-132.

DVORSKÝ, F., 1914: Strážnický okres. Vlastivěda Moravská. Místopis Moravy II., Hradištský kraj. Brno.

JAN, L., 2002: Počátky Strážnice a panství pánů z Kravař. In: Strážnice, kapitoly z dějin města (Pajer, J., ed.), 45-74. Strážnice.

KŘIVÁNEK, R., 2004: Geofyzikální metody. In: Nedestruktivní archeologie. Teorie, metody a cíle Non-destructive archaeology. Theory, methods and goals (Kuna, M., ed.), 117-183. Praha.

MĚŘÍNSKÝ, Z., 1974: Nálezy středověké keramiky z trati „Vojšice“" u Malé Vrbky, PV 1973, 76-77.

MILO, P., 2009: Geofyzikálny prieskum včasnostredovekých sídlisk - prínos pre archeológiu alebo strata času? In: Archeologie doby hradištní (Dresler, P.-Měřínský, Z., edd.), 38-53. Brno.

- 2013: Geofyzikálne prieskumy včasnostredovekých sídliskových lokalít na dolnom Podyjí - Geophysical investigations of early medieval occupation sites in the lower Dyje (Thaya) River region, AR LXV, 706-734.

- 2014: Frühmittelalterliche Siedlungen in Mitteleuropa. Eine vergleichende Strukturanalyse durch Archäologie und Geophysik. Studien zur Archäologie Europas. Vol. 21. Bonn.

MITÁČEK, J., 2008: „Campus Lucsco“ - proměny jedné otázky. In: Východní Morava v 10. až 14. století (Galuška, L.-Kouřil, P.-Mitáček, J., edd.), 155-167. Brno.

MZD I: Moravské zemské desky - Die Landtafel des Markgrafthumes Mähren I. 1348-1466 (Chlumecký, P.-Chytil, J.-Demuth, K.-Wolfskron, A., edd.). Brünn 1856.

NEKUDA, V., 1961: Zaniklé osady na Moravě v období feudalismu. Brno.

- 1975: Pfafenschlag. Zaniklá středověká ves u Slavonic. Př́íspěvek k dějinám středověké vesnice. Brno.

NEKUDA, V.-UNGER, J., 1981: Hrádky a tvrze na Moravě. Brno.

PAJER, J., 2011: Via exploratorum de Bohemia (úvaha o tzv. Cestě českých stráží), Slovácko LII (2010), 203-214.

PAJER, J., a kol., 2002: Strážnice. Kapitoly z dějin města. Strážnice.

PAJER, J., a kol., 2011: Kněždub. Minulost a současnost obce. Kněždub.

PAVELČÍK, J., 1991: Středověká zaniklá osada Vojšice u Hrubé Vrbky (okr. Hodonín), PV 1988, 65.

PAVLÍK, J., 2011: Hrubá Vrbka. Původní nezkrácené a redakčně neupravené znění, př́iloha na CD. Hrubá Vrbka.

RI XI/1: Regesta Imperii XI, Regesten Kaiser Sigismunds (1410-1437). Band 1 (Elbel, P., ed.). Wien Köln - Weimar 2012.

SNÁŠIL, R., 1972: Povrchový průzkum v trati Vojšice u Malé Vrbky (okr. Hodonín), PV 1971, 107-110.

TRIBULA, J., 1973: Středověké nálezy z tratě Vojšice u Malé Vrbky (obec Malá Vrbka), PV 1972, $82-83$.

TRIBULA, J.-UNGER, J., 1970: Zjištovací výzkum na lokalitě „Žižkův stůl“ u Malé Vrbky (katastr Hrubá Vrbka, okr. Hodonín). In: Referáty z I. pracovní porady mladých archeologů oblastních a městských muzeí se zvláštním zřetelem k problematice historické archeologie na Moravě. Př́iloha VVM XXII, č. 3 (Michna, P.-Unger, J., edd.), 95-100. Brno.

UNGER, J., 1967: Der Turmhügel Žižkův stůl bei Malá Vrbka (Bezirk Hodonín), SPFFBU E 12, 232-233.

VAVŘINEC Z BŘEZOVÉ: Vavřinec z Březové, Husitská kronika. Píseň vítězství u Domažlic (Bláhová, M., ed.). Praha 1979. 


\section{Zusammenfassung}

\section{Zerstörungsfreie Untersuchung der Feldsysteme und der Bebauungsstruktur der mittelal- terlich Dorfwüstung Vojšice}

Die Dorfwüstung Vojšice befindet sich an der Katastergrenze der Gemeinden Kněždub und Hrubá Vrbka, und zwar nicht ganz 3,6 km westlich vom Zentrum der zweitgenannten Gemeinde. Die Fundstelle befindet sich auf den gesetzlich geschützten Wiesen des zum Landschaftsschutzpark Weiße Karpaten gehörenden Naturreservates Čertoryje in leicht abschüssigem Gelände und in einer ungefähren Höhe von $360 \mathrm{~m}$ über dem Meeresspiegel. Westlich von der Dorfwüstung verläuft der Bach Radějovka, der den nahegelegenen Hügel Čertoryje von Osten her umfließt.

In keiner der uns bekannten schriftlichen Quellen ist eine direkte Erwähnung des Dorfes überliefert. Den Ortsansässigen ist die Fundstelle gut bekannt, jedoch gelangte sie erst in den siebziger Jahren des 20. Jahrhunderts ins breitere Bewusstsein, als man die umliegenden Wiesen offensichtlich zum ersten Mal seit dem Mittelalter als Ersatz für die für Bauten im Rahmen der sozialistischen Planwirtschaft eingezogenen Bodenflächen für den Ackerbau bereitstellte. Dank der gemachten Keramikfunde und eines Eisensporns konnte die Fundstelle nicht nur in die Zeit des Hochmittelalters datiert werden, sondern auch in die Vorzeit. Außer in die Vorzeit und in die Protogeschichte kann das dabei veröffentlichte und heute verfügbare Material in die zweite Hälfte des 13. Jahrhunderts bis zum 14. Jahrhundert datiert werden (Měřínský 1974, 76-77, Tab. 80; Snášil 1972, 107-109; Tribula 1973, 82-83). Die Dorfachse soll den entdeckten Funden nach vom Bach Radějovka (früher Vojšicer-Bach) gebildet worden sein, wobei bei seiner Begradigung und dem an ihn angrenzenden Ackerbau einzelne Anwesen sichtbar geworden sein sollen (Snášil 1972, 107-109).

Außer auf das Dorf selbst wandte sich die Aufmerksamkeit der Archäologen auch auf den sog. „Žižka-Tisch“, eine vom Bach Radějovka umflossene unscheinbare Anhöhe, wo sich eine kleine mittelalterliche Befestigung befunden haben soll. Durch eine archäologische Sondierungsgrabung konnte diese Annahme jedoch nicht ganz bestätigt werden. Von den Autoren der Grabung (J. Tribula und J. Unger) wurde die Befestigung zunächst als Kastell angesehen, später wurde sie von ihnen als geschützter Ort bezeichnet. R. Snášil hingegen interpretiert das Relikt als Überrest einer speziellen Wirtschafts- oder Produktionsanlage - wahrscheinlich einer Wassermühle (Nekuda 1961, 157; Unger 1967, 232-233; Nekuda-Unger 1981, 315-316; Snášil 1972, 107-109; Tribula-Unger 1970, 95-100).

Dank einer Kombination der Methoden der Fernerkundung, des Studiums historischer Quellen und der geophysikalischen Prospektion ist es gelungen, in der Umgebung der mittelalterlichen Dorfwüstung Vojšice mindestens zwei voneinander unabhängige Feldsysteme zu identifizieren, von denen eins anhand der verfügbaren Erkenntnisse in der mittelalterlichen Dorfwüstung in Verbindung gebracht werden kann. Eine interessante Feststellung ist auch die Tradition, dass die Grenzen der einzelnen Parzellen bis in die heutigen Tage beibehalten wurden und die Katastergliederung an die ältere mittelalterliche und frühneuzeitliche Eigentumssituation anknüpft. Gemäß der Geländekonfiguration ist es offensichtlich, dass sich die zum Dorf gehörenden Ländereien am rechten Ufer des Baches Radějovka befanden, das weniger abschüssig ist. Das linke Steilufer hat man wohl nur vereinzelt oder nur bis zu einer gewissen Entfernung genutzt und diente $a b$ der frühen Neuzeit eher nur als Weide. Leider wurde das rechte Ufer über lange zwanzig Jahre hinweg mit modernen landwirtschaftlichen Mitteln intensiv bepflügt, wodurch ältere Besiedelungsspuren verwischt und auch die Überreste der Dorfwüstung selbst deutlich gestört wurden, die sich lediglich in die zweite Hälfte des 13. und in den Verlauf des 14. Jahrhunderts datieren lassen. Datierung und Entstehung des zweiten Systems kann ohne eine intensive Zusammenarbeit mit den naturwissenschaftlichen Disziplinen und ohne systematische Grabung vorerst nicht geklärt werden. 
Die vorliegende Studie wurde im Rahmen des spezifischenForschungsprojektes MUNI/0930/2018 „Archäologische Geländeprospektion, Aushebungen, Dokumentation und Museumspräsentation VIII“ erstellt.

Mgr. Miroslav Dejmal, Archaia Brno, z. ú., Bezručova 15, 60200 Brno, Česká republika, mdejmal@archaiabrno.cz

Mgr. Petr Dresler, Ph.D., Ústav archeologie a muzeologie Filozofické fakulty Masarykovy univerzity, Arna Nováka 1, 60200 Brno, Česká republika,dresler@phil.muni.cz

Dr. phil. Peter Milo, Ústav archeologie a muzeologie Filozofické fakulty Masarykovy univerzity, Arna Nováka 1, 60200 Brno, Česká republika,101090@phil.muni.cz

Mgr. Tomáš Tencer, Ústav archeologie a muzeologie Filozofické fakulty Masarykovy univerzity, Arna Nováka 1, 60200 Brno, Česká republika,tomastencer@phil.muni.cz

Mgr. Michal Vágner, Ústav archeologie a muzeologie Filozofické fakulty Masarykovy univerzity, Arna Nováka 1, 60200 Brno, Česká republika,vagnermichal@mail.muni.cz 
